\title{
A comparison of Main Central Thrust and other Himalayan fault systems from central and west Nepal with some two-dimensional stress fields
}

\author{
Megh R Dhital \\ Central Department of Geology, Tribhuvan University, Kirtipur, Kathmandu, NEPAL \\ For correspondence, E-mail:mrdhital@wlink.com.np
}

Like the entire Himalayan range, the Main Central Thrust (MCT) in central and west Nepal constituted a single sheet, which was subsequently eroded away giving rise to various klippe and windows. Detailed field mapping in central and west Nepal revealed that the MCT is a sharp thrust fault along which there has been a movement of more than $80 \mathrm{~km}$. As a rule, in this area the hanging wall of the MCT includes sillimanite-grade rocks in the inner belt and garnet-grade rocks in the outer belt. The MCT overrides the Lesser Himalayan rocks, whose grade of metamorphism also decreases from the inner to outer belt. On the other hand, the hanging wall of the MCT frequently contains a zone of retrograde (inverted) metamorphism at the base followed by a zone of prograde (normal) metamorphism towards the top, whereas the footwall always reveals a prograde (inverted) metamorphism towards the inner belt.

Though inverted metamorphism in the footwall is generally attributed to the MCT, such a relationship is inconsistent with the present field observations. For example, in the Melamchi Khola area to NE of Kathmandu at Majhitar the hanging wall of the MCT contains sillimanite-gneiss, which overrides the Benighat Slates and Dunga Quartzite of the Lesser Himalayan footwall. Similarly, in the Mahesh Khola - Belkhu area to SW of Kathmandu, the MCT also contains sillimanite gneisses and migmatites which rest over slates and phyllites of the Lesser Himalaya. But along the strike of the MCT, grade of metamorphism of the hanging wall decreases substantially towards SW to the garnet grade whereas the footwall rocks remain almost unaffected. On the other hand, in the inner belt of the Barpak area, the footwall rocks have undergone a wide zone of inverted metamorphism up to the kyanite grade.

Around Kathmandu, the MCT is folded to form the Mahabharat Synclinorium, where the augen gneisses are confined to the periphery of the Synclinorium and granites occupy only the core zone. This fact as well as the presence of

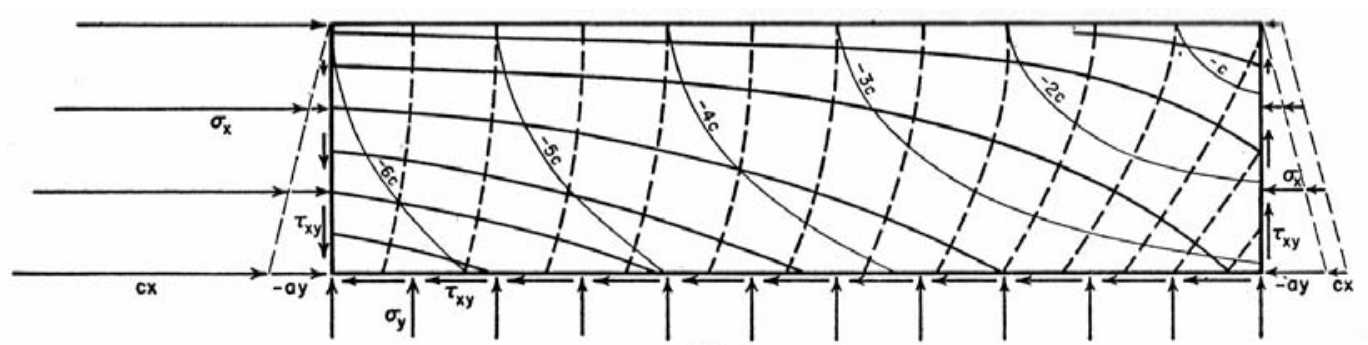

(a)

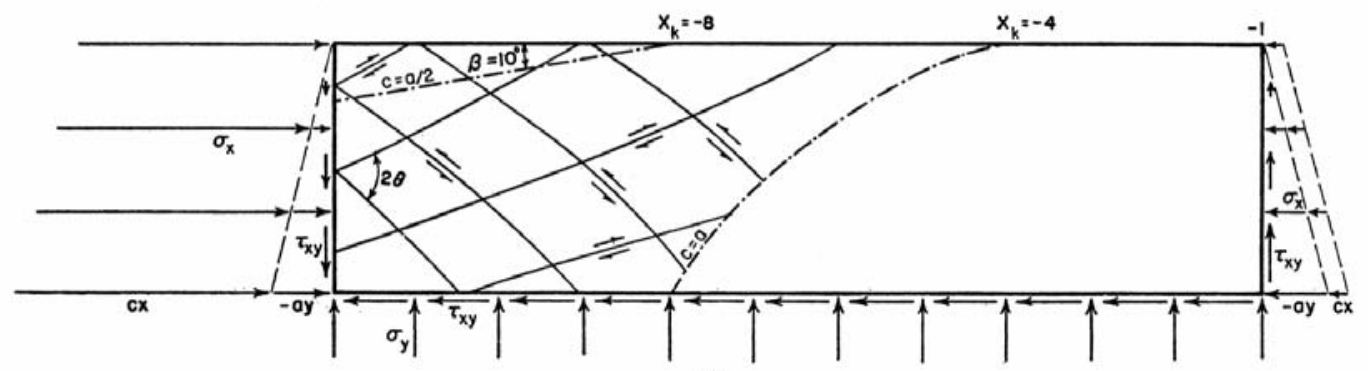

INTERNAL AND BOUNDARY STRESSES:

(b)
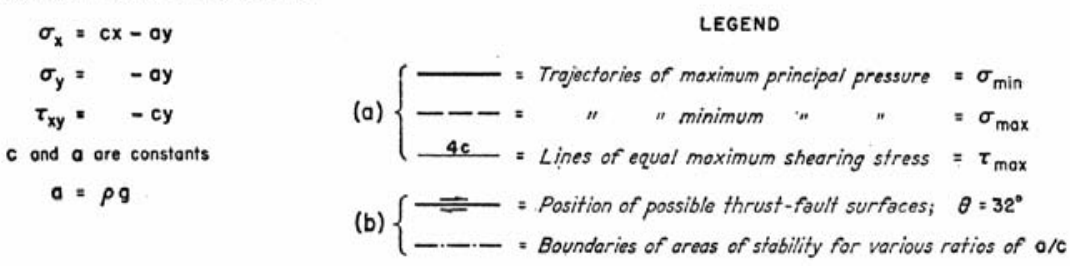

FIGURE 1. Supplementary stress system consisting of superimposed horizontal pressure constant with depth and with constant lateral gradient (Hafner 1951). Note that the trajectories of maximum principal compressive stress (principal pressure) are converging towards the top left, indicating an increase in their magnitude 
xenoliths of schist and quartzite in them together with their identical mineral composition clearly point out to the igneous origin of the augen gneisses, most probably derived from the same type of granites. In the Lima Khola area of west Nepal, the MCT forms a small klippe of garnetiferous schist and quartzite, and it is the continuation of the Mahabharat Synclinorium. Hence, there were remarkable tectonic movements after the emplacement of the MCT in central and west Nepal.

Imbricate faults prevail in the Siwaliks and the Lesser Himalaya of Nepal. Though they frequently dip to the north, some of them also dip to the south, forming back thrusts. Such back thrusts were mapped in the Siwaliks of west Nepal and the Lesser Himalayan rocks of the Kusma - Syangja area. Most of the imbricate faults in the Lesser Himalaya formed duplexes in the past and were subsequently exposed after erosion of their roof thrust.

Hafner (1951) obtained an exact solution of stress fields using simple polynomials that satisfy the biharmonic equations for Airy's stress function. He determined the stress distribution to explain fault orientations in a two-dimensional, isotropic, continuous, elastic, and static body taking a variety of horizontal compressive or shear stresses expected in the earth's crust as boundary conditions for the bodies, and predicted the fault types in the earth's crust (Figure 1). On the other hand, Sanford (1959) studied the stresses in a uniform upper layer caused by movements of the basement. He also obtained an exact solution on the elastic theory and derived the stress fields (Figure 2).
The similarity between the predicted fault system based on Hafner's stress field and the Himalayan faults like the MCT and other faults in the Lesser Himalaya and Siwaliks is remarkable (Figure 1). The theoretically predicted listric faults closely resemble the foreland- as well as hinterland- vergent imbricate thrusts. On the other hand, the compressive principal stress trajectories converge (implying their increasing magnitude) towards the top left and so does the average shear stress. This process could ultimately be responsible for the inverted metamorphism in the Himalayas. In these circumstances, thrusting along the MCT and the prograde inverted metamorphism could be two independent phenomena, whereas the retrograde inverted metamorphism is probably related to the movement along the MCT.

Since there is no evidence of South Tibetan Detachment system and other normal faults in the outer Higher Himalayan belt, it is clear that the fault post-dated the MCT. One of the explanations of the extensional tectonics in the Trans Himalayan range could be due to the subsequent uplift of the basement. In this regard, Sanford's stress field (Figure 2) can successfully explain such a phenomenon.

\section{References}

Hafner W 1951. Stress distributions and faulting. Geol Soc Amer Bull 62: 373-398

Sanford, AR 1959. Analytical and experimental study of simple geologic structures. Geol Soc Amer Bull 70: 19-52
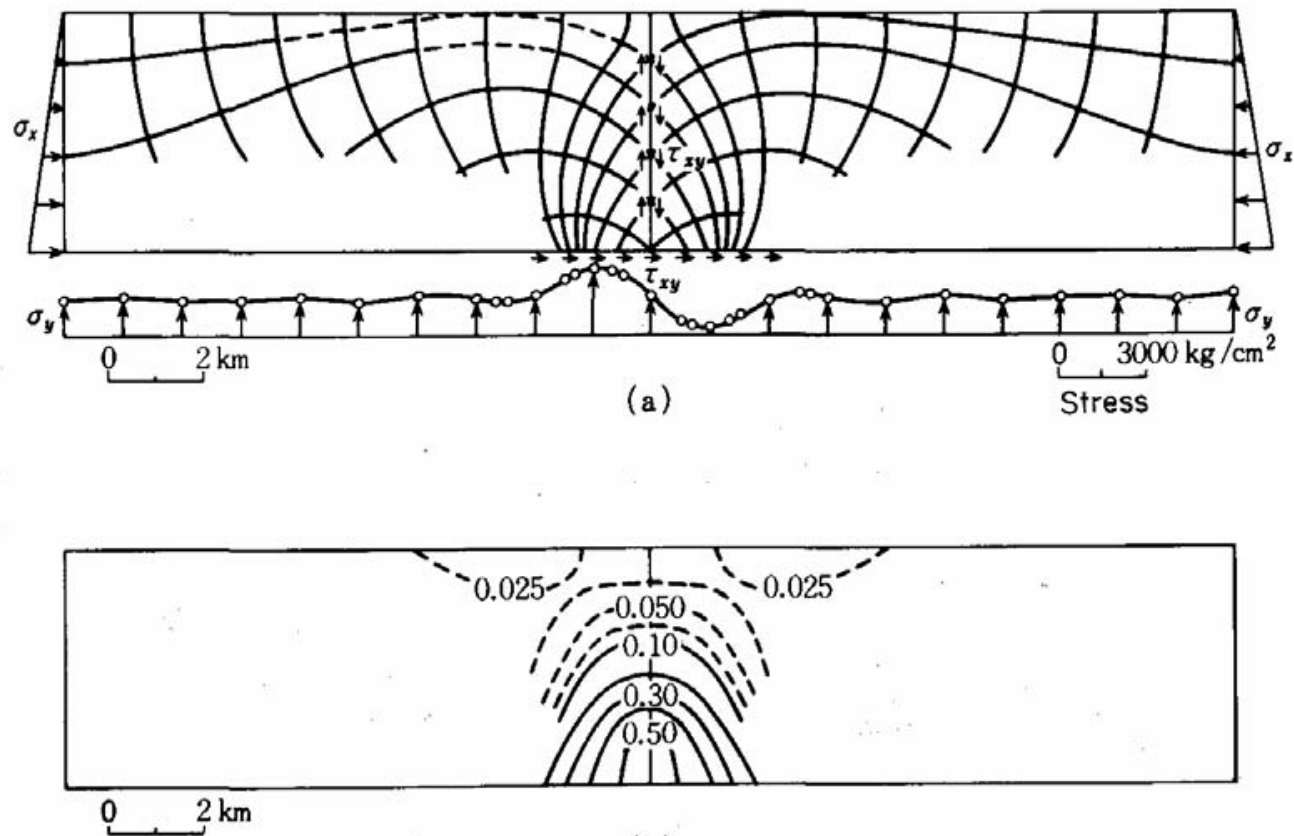

(b)

FIGURE 2. Stress field generated inside elastic layer resulting from step-like displacement in the basement. (a) Stress distribution (solid line: compression, broken line: tension). (b) Distortional strain energy distribution. Units in $\mathrm{kg} / \mathrm{cm}^{2}$ (Sanford 1959) 